Available online on 15.09.2020 at http://jddtonline.info
Open Access to Pharmaceutical and Medical Research
unrestricted non-commercial use, provided the original work is properly cited

Open Access

Research Article

\title{
Contribution to the study of xylophagus insects and their role in the decline of Alep pine (Pinus halepensis mill.) in El Ouldja's Megsem forest (Setif - Algeria)
}

\author{
Noureddine Laadel $^{1 *}$, Farida Benia1, Abdelmalek Oulmi² and Sofiane Guettaf ${ }^{3}$ \\ 1 Laboratory of Improvement and development of plant and animal production, Faculty of Nature and Life Science, Ferhat Abbas University \\ Sétif-1, Sétif 19000, Algeria \\ ${ }^{2}$ Laboratory for the Valorization of Natural Biological Resources, Faculty of Nature and Life Science, Ferhat Abbas University Sétif-1, Sétif \\ 19000, Algeria \\ ${ }^{3}$ Laboratory of Applied Microbiology, Faculty of Nature and Life Science , Ferhat Abbas University Sétif-1, Sétif 19000, Algeria
}

\begin{abstract}
Pinus halepensis Mill., is an essence from the Pinaceae family. This importance is attributed to its economic and aesthetic values. Despite its robustness, this tree is subject to many degradation factors including, for some time, that of wood-boring insects which for the most part are fatal. The purpose of this investigation is to classify these insects, define their role in pine decline and evaluate the damage caused by them in the Megsem forest. The result of the study shows that members of the Curculionidae, Cerambycidae and Buprestidae families could be held responsible for the majority of the damage observed on the pine
\end{abstract}

Keywords: Pinus halepensis, decline, Megsem, wood-boring insects, Algeria

Article Info: Received 06 July 2020; Review Completed 19 Aug 2020; Accepted 27 August 2020; Available online 15 September 2020

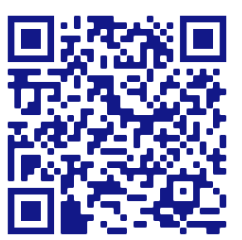

Cite this article as:

Laadel N, Benia F, Oulmi A, Guettaf S, Contribution to the study of xylophagus insects and their role in the decline of Alep pine (Pinus halepensis mill.) in El Ouldja's Megsem forest (Setif - Algeria), Journal of Drug Delivery and Therapeutics. 2020; 10(5):106-107 http://dx.doi.org/10.22270/jddt.v10i5.4385

N. Laadel, Laboratory of Improvement and development of plant and animal production, Faculty of Nature and Life Science, Ferhat Abbas University Sétif-1, Sétif 19000, Algeria

\section{INTRODUCTION}

In Algeria, the forests of Aleppo pine (Pinus halepensis Mill.) Cover more than 850,000 hectares. This species, which is present in all bioclimatic stages, from the coast to the Saharan Atlas, finds its optimum growth mainly in semi-arid zone. Its great plasticity and robust temperament have made it a pioneer in large reforestation 5 .The Aleppo pine occupies a fragmented area throughout the Mediterranean carrier. On European shores, it is present in Spain. France (in the Mediterranean region, up to $600-800 \mathrm{~m}$ on the southern slopes). Italy, and Greece. In North Africa ${ }^{1}$. It is also present in the mountains and the Tunisian ridge and in Morocco. It is found in the Rif, the Middle and the Great Atlas, it is also found in the east: Palestine, Jordan, Lebanon, Syria, Turkey, Albania, Croatia, Ukraine ${ }^{1}$.

The insects adapt to all environments and are associated with a large number of plant and animal organisms. Some are useful, but many are harmful. By their diet, they can be phytophagous, xylophagous, saprophagous, and therefore can be the source of defoliations and other destruction of plantations, and this across a whole country. Also, knowing the pest species in particular and the entomofauna in general will allow us to better understand the decline problem that affects these important species, and which will allow us to better fight against the main enemies. Several families of xylophagous insects are responsible for the attacks. Among these insects are the Scolytidae, the Buprestidae, the Cerambycidae and the Curculionidae. The Scolytidae family is placed by many authors in the first rank of natural enemies of coniferous forests and they are responsible for $90 \%$ of the damage ${ }^{3}$.

The aim of this study is to describe the entomological stands of pine, and to highlight the role of xylophagous insects in the decline of pine, knowing that no synecological research had been carried out. in this area at regional level.

\section{MATERIALS AND METHODS}

The first stage of this research was devoted to carrying out a faunistic inventory of xylophages at the Study area mentioned below (Fig. 1) using two trapping techniques, namely the glass trap and the trap trees. After analyzing 
several tree samples in the field, we have found that pine's decline begins at the treetop and progressively extends to the entire tree, resulting in foliage color alteration and defoliation.

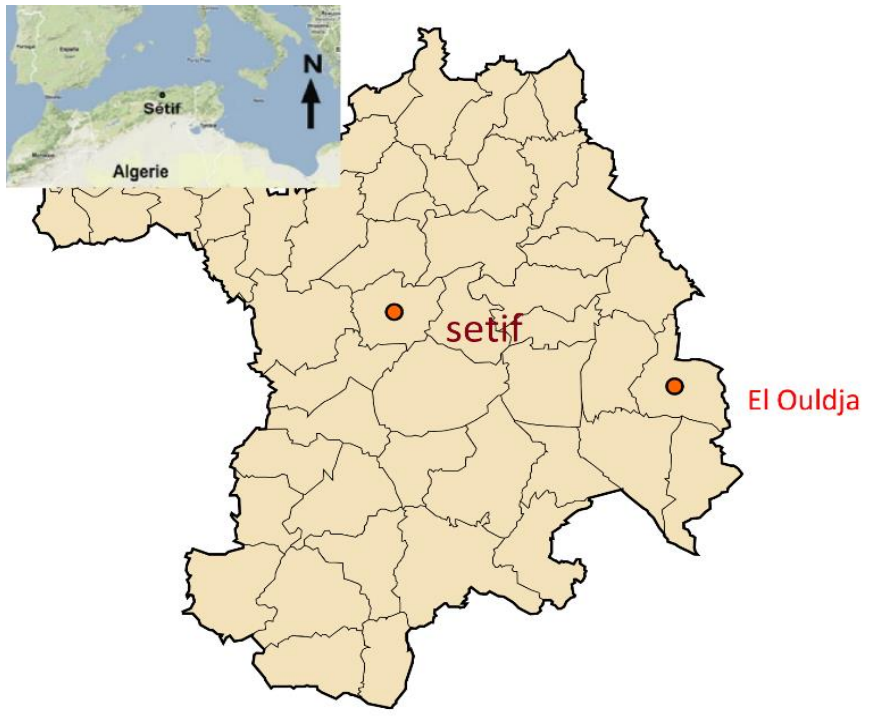

Figure 1: Location map of the study area.

\section{Trapping methods}

\section{Glass trap}

The principle consists of intercepting insects during their phases of aerial movement. We use the tendency of coleopterans to drop when they encounter an obstacle during flight.

to make the glass trap consists of two sheets of transparent plexiglass $(80 \times 40 \times 0.3) \mathrm{cm}$, which represents a collection area of $0.64 \mathrm{~m} 2$. The roof is $45 \times 45 \mathrm{~cm}$, on the lower part is fixed a funnel $45 \mathrm{~cm}$ in diameter, allowing the sliding of the insects in a recuperator filled with $3 / 4$ of salt water $15-20 \%$ $\mathrm{NaCl}$ ) and 'detergent. The latter, which is a surfactant, is added to facilitate the immersion of insects and to limit the escape $^{2}$.

\section{Trap trees}

This method requires sections 40 to $50 \mathrm{~cm}$ in length and dying branches to house beetles. It consists of cutting down middle-aged pine trees, and exposing them to attack by xylophagous insects, during the swarming period, that is to say when the adults leave their biotope of birth to look for a new biotope conducive to egg laying. The trees thus felled stay in nature for a few days to coincide with the attack period before they are hawked to the laboratory.

This technique is based on the principle that insects lay eggs on recently cut wood, attracted by a spectrum of odors (terpene compounds) ${ }^{4}$.

Once, the various xylophagous insects are brought back to the laboratory in small pots, several operations are carried out there (sorting of insects, breeding, conservation and determination).

\section{RESULTS AND DISCUSSION}

The result of this study is to know in particular the xylophagous species of the pine in the deline and to evaluate their harmfulness in the forest of Megsem in El Ouldja (Table. 1)

Table 1: Representation of the number of species by family and percentage (El Ouldja)

\begin{tabular}{|c|c|c|c|}
\hline Orders & Families & Species & Number of individuals \\
\hline Coleoptera & Curculionidae & Orthotomicus erosus & 6 \\
& & Rhyncolus sp & 6 \\
& & Pityogenes bidentatus & 7 \\
& & Pityogenes calcaratus & 9 \\
& & Hylurgus ligniperda & 8 \\
& & Tomicus piniperda & 6 \\
\hline & & Hylobius sp & 4 \\
\hline & Buprestidae & Chalcophora mariana & 8 \\
\hline & Cerambycidae & Criocephalus rusticus & 6 \\
\hline & Histeridae & Platysona angustatus & 7 \\
\hline
\end{tabular}

Table 1 shows that the entomofauna in the forest of Megsem in El Ouldja has a considerable diversity of xylophagous coleoptera. 
Table 2: Representation of the number of species by family and percentage (El Ouldja)

\begin{tabular}{|c|c|c|}
\hline Families & Number of species & Percent \% \\
\hline Curculionidae & 7 & 93.63 \\
\hline Buprestidae & 1 & 9.09 \\
\hline Cerambycidae & 1 & 9.09 \\
\hline Histeridae & 1 & 9.09 \\
\hline Colydiidae & 1 & 9.09 \\
\hline
\end{tabular}

Table 2 shows that the entomofauna associated with dying trees are rich and diverse. The most important family is that of Curculionidae with 7 species with a rate of $63.63 \%$. Buprestidae, Cerambycidae, Histeridae and Colydiidae come last with one species for each with a rate of $9.09 \%$.

In relation to families, the following histogram shows the relative importance of the coleoptera family (Fig. 2)

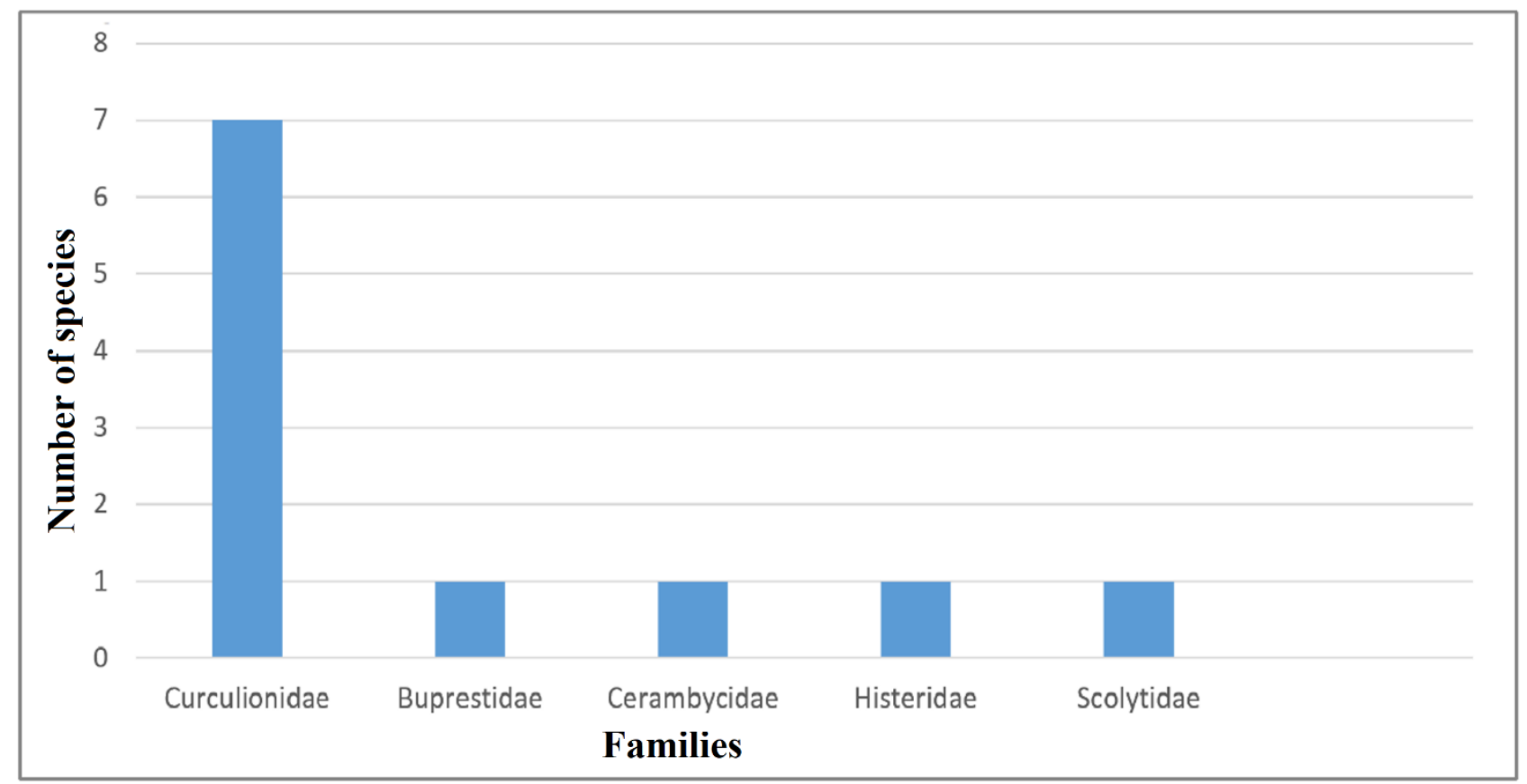

Figure 2: Histogram representing the relative importance of Coleoptera families.

This histogram (Fig. 2) therefore highlights the xylophagous coleoptera harmful in the forest of Megsem in El Ouldja

This huge speed of decline shows the extent of the damage economic effects caused by these often overlooked insects. To answer this problem, it it was necessary to reconsider these insects in their real context and to seek techniques of appropriate control.

\section{CONCLUSION}

The analysis of the different families makes it possible to know that for most of the species are xylophagous and harmful pests, and that with a high number of species, case of Curculionidae and only one very dangerous species case of Tomicus piniperda of the same family.

It appears that the damage committed in this pine forest is probably the result of a certain level of xylophagous insects living at the expense of suffering trees,

To implement a strategy to protect these ecosystems against parasitic attacks, research must be directed towards various multidisciplinary approaches (biological, physiological, pedological, mycological, etc.). This strategy must be complemented by several remediation actions, including the removal of dead trees from the forest to avoid their contamination or bring insect population levels below an epidemic threshold. The reforestation of areas bare of the same type of trees and the permanent intervention of the forester are even more effective measures.

\section{RÉFÉRENCES}

[1] Arbez M et al. Les ressources génétiques forestières en France, Tome 1 : Les conifères. Paris, INRA-BRG. 1987.

[2] Bouget C, Échantillonnage des communautés des Coléoptères Carabiques en milieu forestier. Relations espèces-milieu et variations d'efficacité du piège à fosse. Symbioses, 2001; 4:55-64.

[3] Chararas C, Les insectes parasites des forêts. La Recherche, 1982; 132(13):440-451.

[4] Chararas C, Sélection de la plante hôte par les Scolytidae et mécanismes d'installation des insectes (attraction primaire et attraction secondaire). Bull. Soc. Ent. Fr., 1986; 91(5-6):137-162.

[5] Mezali M, Rapport sur le secteur forestier en Algérie. 3ème session du forum des Nations Unis sur les forêts, 2003; 9 p. 